\title{
The Influence of Combination of Castor Oil with Aquades on Increasing Moisture over a Dry Skin
}

\section{Nurul Hidayah and Titin Supiani}

Cosmetology Vocational Education, Faculty of Engineering, State University of Jakarta

\section{Abstract}

The aim of the research is to determine the combination of castor oil and aquades to increase moisture over a dry skin. Part of the skin chosen for the research is face, elbow, and heel. The sample was taken through experiment method of purposive sampling. Total sample that have been classified is 15: 5 samples use combination of castor oil with aquades 15\%, 5 samples use the combination of castor oil with aquades $10 \%$, and 5 samples use the combination of castor oil with aquades $5 \%$. Results show that the castor oil with aquades $15 \%$ increases the value of 0.246 which means data is

Corresponding Author: Nurul Hidayah nrl.hdy@gmail.com

Received: 11 January 2019 Accepted: 14 February 2019 Published: 25 March 2019

Publishing services provided by Knowledge E

(c) Nurul Hidayah and Titin Supiani. This article is distributed under the terms of the Commons Attribution License, which permits unrestricted use and redistribution provided that the original author and source are credited.

Selection and Peer-review under the responsibility of the 3rd ICTVET 2018 Conference Committee.

\section{G OPEN ACCESS} normal, and in castor oil with aquades 10\%, there was a rise in the value of the mean 0.279 data is normal and castor oil with aquades $5 \%$, there was a rise in the value of the 0.254 means data is normal. On the test of the hypothesis means the data $\mathrm{HO}$ is rejected and $\mathrm{H} 1$ accepted. This means that there is an influence on the use of castor oil with aquades against moisture results dry skin. So the results of the study showed that there was a score of increasing moisture content of dry skin by using a mixture of castor oil with aquades. It is known that castor oil contains high fat of linoleic acid and aquades that has neutral properties so that the mixture of castor oil with aquades still contains high oil.

Keywords: moisturize, dry skin, face, elbow, heel, castor oil, aquades

\section{Introduction}

The skin is a blanket that covers the surface of the body and has a primary function as protectors of the various disorders and external stimuli [1]. Dry skin begins to occur in women near the age of 30 , because the ability of the skin to hold moisture decreases. Areas of dry skin on the body occur faster on the skin face, elbow and heel of the foot, the urgency if the skin is too dry it will cause the skin to rough texture, crack causing less confidence. This research aims to help improve dry skin conditions. If dry skin is another form of active thyroid gland does not sign the case if oil levels balance 
is disturbed, dry skin look dull and rough texture [2]. The less amount of water between the chains, the stronger the bond and the lower elasticity of the certain of the stratum corneum, so that the skin will dry, dry skin is skin that feels stiff, cracked and hard. Common conditions experienced by the skin where there is a lack of fluid in the outer layer of the skin. Open body parts, such as the arms, hands and feet are the areas most susceptible to this disorder [3]. Skin that experiences premature aging causes the skin's moisture value to decrease so that the skin becomes dry. The reduced value of skin moisture can be overcome by providing care for the skin [4]. When the skin is not well maintained and regularly, it is easy to get disturbances such as cracked skin, so it requires special care for the skin. In dry skin must to protect by maintain existing skin fat using cosmetics that contain base oils, moisturizers or emollient ingredients to protect the evaporation of water from the skin. The fat moisturizers commonly used are lanolin, fat wool, high fat alcohol, lanette wax, glycerol monostearate, etc. In addition is a mixture of oils such as plant oils, which are better than mineral oils because they are easier to mix with skin fat, are better able to penetrate stratum corneum cells and have a stronger adhesion force [5]. A moisturizing cream is essential to any anti-wrinkle treatment plan. Daily moisturizing of the skin will make it softer, vibrant, and healthier and thus cream could be formulated by having all ingredients natural oils even there is no need to add preservative because ethanol itself act as preservative. So the cream can be formulated by taking natural ingredients like olive oil, almond oil, and tocopherol and neem oil, soya meal powder and for base we can use cocoa

butter or bees wax and lanolin [6]. Natural ingredients from plants that are usually processed into oil, namely castor oil. Based on the information obtained in the book market prospects and distance crop cultivation, that the initial castor oil was intended for medicinal lighting oil, and cosmetic ingredients. Very high coarse fat in the content of castor seeds is widely used as an emulsion in most cosmetics to increase moisture in dry skin. Processing of castor seeds into oil is done by pressing and then squeezing the oil. Based on information obtained in a market prospect and cultivation of distance, that the main results of the plant distance is the fruit made up $20 \%$ of the fiber material (fruit leather) and $80 \%$ of seeds containing oil of approximately $40-60 \%$ with the nature is not easy dries (nondrying oil) initially intended for oil castor oil lamp lighting among other drugs to wash stomach, as an oil rub, and cosmetic ingredients [7].

Castor oil contain much and very rich Acid of linoleate, castor oil that has been processed and then mixed with aquades to reduce high viscosity if it is attached to dry skin. Castor oil is very easily absorbed by the skin and is very good in helping moisturize the skin. This castor seed oil can be used for skin health and beauty especially to 


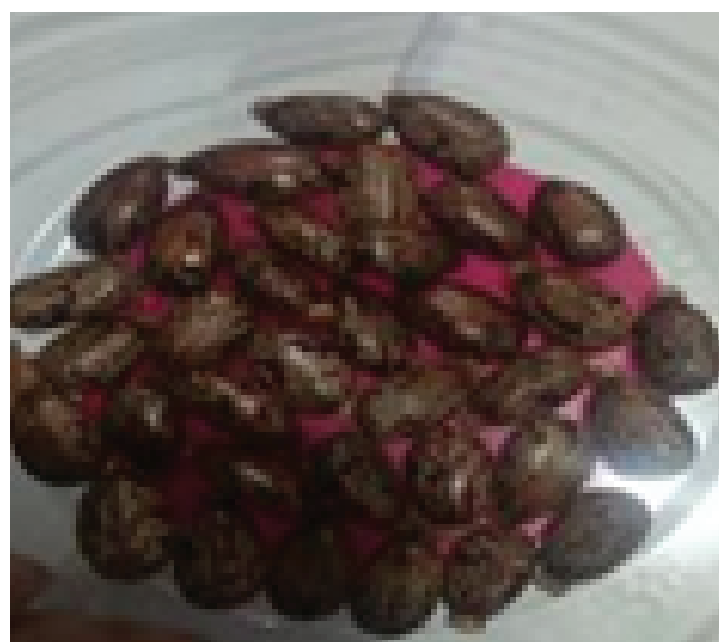

Figure 1: Jarak kepyar.

moisturize dry skin, the use of castor oil on the skin can be applied directly to the surface of the dry skin regularly to get the expected results. The effect of oil as a herbal although known from the journal Pharmacy "Herbal ingredients are not only efficacious to treat skin dryness as compare to synthetic one but also capable to substitute synthetic base to some extent. It is up to the cosmetologist to motivate and encourage the development and use of truly herbal cosmetics [8]. The preliminary study was carried out by processing $500 \mathrm{~g}$ of Kepyar castor oil by cold press, processing of castor seeds into oil is done by pressing (pressing) and then squeezing the oil [9].

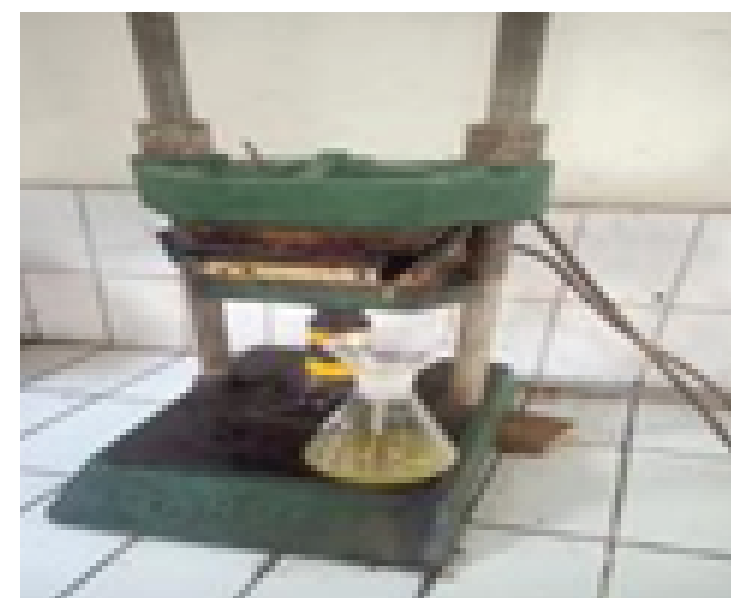

Figure 2: Cold Pressing castor oil.

In pressing units the distance seeds are cleaned through an aspirator machine and then accommodated. Pressing is done on an expeller with screw press which produces crude castor oil then purification into pure castor oil [10]. After becoming pure castor oil, laboratory tests are conducted to determine the content of castor oil. This research 
was conducted in the Mulatama Laboratory. Based on the laboratory test, the contents are found in the table below:

TABLE 1: The Content of Castor Oil.

\begin{tabular}{|l|c|c|c|}
\hline No. & Parameter & EBJ & Unit \\
\hline 1 & Risin & 89.52 & gram \\
\hline 2 & Dehidrosistrearat & 1.385 & gram \\
\hline 3 & Acid of Palmitat & 1.125 & gram \\
\hline 4 & Acid of stearate & 1.155 & gram \\
\hline 5 & Acid of Oleat & 3.125 & gram \\
\hline 6 & Acid of linolenat & 0.185 & gram \\
\hline 7 & Acid of Linoleate & 3.385 & gram \\
\hline 8 & Emolien/Dioktyl azelate & 0.115 & gram \\
\hline Source: Laboratory of Mulatama, 2018. & \\
\hline
\end{tabular}

Based on the results of the above laboratory tests it is known in 100 grams, castor seed oil contains ricin, dehydrosistrearat, palmitic acid, stearate acid, oleic acid, linoleic acid, linoleic acid, emollient/dioxytyl azelate [11]. Castor oil is herbal that contains linoleic acid, linoleic acid, and emollient natural ingredients from plants. The results of this research are expected to produce in the form kepyar that can be used easily wherever and whenever. Castor oil is providing solutions to moisturize dry skin. Products that have advantages in accordance with science and technology. The packaged castor oil can be one of the beauty cosmetics that is useful for moisturizing dry skin easier anywhere.

\section{Methods and Equipment}

\subsection{Methods}

\subsubsection{Diagrammatic representation}

This study uses experimental research methods. This research was carried out in the lab Prody Cosmetology, engineering faculty - State University of Jakarta. Research time during 4 weeks, starting on August-September 2018. Sampling is 15 samples divided into 3 groups with dry skin conditions on face, elbow and heel. The sample of 5 people used a mixture of castor oil with 15\% aquades, sample of 5 people used a mixture of castor oil with $10 \%$ aquades and 5 samples using a mixture of castor oil with $5 \%$ aquades. The sample selection in this study use purposive sampling, with specified criteria: 30-40 year women, dry skin or normal little dry skin, there are no injuries or inflammation in the skin, not suffering from organ diseases. Engineering data retrieval, data that are found 
are primary data generated through experiments using measuring instruments to the skin's moisture analyzer test. Several stages of research conducted include: Preliminary study, formulating problems, choosing approaches, determining data sources, arranging instruments, experiments, analyzing data, and drawing conclusions. Treatment dry skin with castor oil and aquades need tools, cosmetics and materials: cup fruit container to dispense oil, wash small lap, dropper bottles, the wash cloth 1 piece help clean up after the treatment of warm water To cleanse the skin, castor seed oil $15 \mathrm{ml}$ to moisturize dry skin

\subsubsection{Instrument}

The instrument used to measure moisture content uses a skin analyzer test [12]. This tool uses BIA (Bioelectrical Impedance Analysis) technology to see the dryness of dry skin. Works by giving a signal in the form of a number that will be displayed on the LCD screen according to the measurement level value.

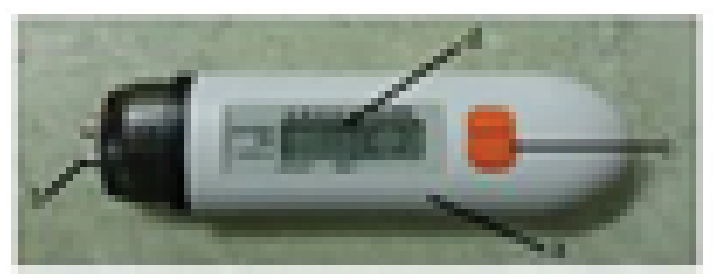

Figure 3: Skin analyzer test.

This tool will automatically detect skin condition factors, such as moisture (moisture), oil content (oil) and skin surface texture (rough / soft). Size results will be displayed on the LCD screen [13].

TABLE 2: The Value of Reference from Monitor of Moisture.

\begin{tabular}{l|c|c|c|c|c} 
Column & $\mathbf{1}$ & $\mathbf{2}$ & $\mathbf{3}$ & $\mathbf{4}$ & $\mathbf{5}$ \\
$\begin{array}{l}\text { Percentage of } \\
\text { water }\end{array}$ & $<=33 \%$ & $34-37 \%$ & $38-42 \%$ & $43-46 \%$ & $>=47 \%$ \\
$\begin{array}{l}\text { Skin Type } \\
\begin{array}{l}\text { Very Dry } \\
\text { Skin }\end{array}\end{array}$ & Dry Skin & $\begin{array}{c}\text { Normal } \\
\text { Skin }\end{array}$ & $\begin{array}{c}\text { Moisture } \\
\text { Skin }\end{array}$ & $\begin{array}{c}\text { Very Moisture } \\
\text { Skin }\end{array}$ \\
\hline Source: Guide book skin analyzer test. & & &
\end{tabular}

This study measures the humidity of the dry skin using the initial test pattern treatment - test end. Initial tests are carried out to determine the condition of the skin before being treated, while the final test is done to find out the results of the increase dry skin to moisture after given treatment. Then the skin is measured by humidity based on criteria instrument lattice below. 
TABLE 3: Moisture instrument lattice.

Aspect
$\begin{aligned} & \text { Indicator } \\ & \text { (1) The device lights up in the water position, showing very dry skin } \\ & \text { condition }<=33 \% \\ & \text { (2) The device lights up in the water position, showing dry skin condition } \\ & \text { with a percentage of } 34-37 \% \\ & \text { (3) The device lights up in the water position, showing normal skin } \\ & \text { conditions with a percentage of } 38-42 \% \\ & \text { (4) The tool lights up in the water position, showing moist skin conditions } \\ & \text { with a percentage of } 43-46 \% \\ & \text { (5) The device lights up in the water position, showing very moist skin } \\ & \text { conditions }>47 \%\end{aligned}$
Note: Moisture measurement of dry skin on the dry skin in part face, elbow and heel is done regularly
every 2 days on days $1,3,6,9,12,15,18,21$. Measurements were made using a skin tool analyzer
test to see the increase in score for each treatment.

\section{Results}

This study uses an experimental design that is Nonequivalent group design. In this design there are three groups that have been determined by the researcher. Data collected in this experiment are primary data generated from experimental results which are divided into 3 groups using a mixture of castor oil with aquades. Data collection is carried out periodically every 2 days after obtaining data from dry skin measurements with a skin analyzer test tool.

TABLE 4: Design of Research.

Group
Moisture of the dry skin on face uses
mixed castor oil with $15 \%$ aquades
Moisture of dry skin on elbow uses mixed
castor oil with $10 \%$ aquades
Moisture of dry skin on heel uses mixed
castor oil with $5 \%$ aquades

\begin{tabular}{|c|c|}
\hline Beginning Test & Treatment \\
\hline$(\mathrm{T} 1)_{A}$ & $\mathrm{X}_{A}$ \\
\hline$(\mathrm{T} 1)_{B}$ & $\mathrm{X}_{B}$ \\
\hline$(\mathrm{T} 1)_{C}$ & $\mathrm{X}_{C}$ \\
\hline
\end{tabular}

Final Test
$(\mathrm{T} 2)_{A}$
$(\mathrm{~T} 2)_{B}$
$(\mathrm{~T} 2)_{C}$

After the above steps then test the data analysis with normality tests performed parametric using an average estimator and standard deviation, then in this section will be shown a nonparametric normality test with the name Kolmogorov Smirnov. After data analysis techniques are carried out, the next step is to change the formula into a statistical hypothesis. Description of Research Data have showed by graphics: 
Combination of castor oil with aquades $15 \%$ for dry skin on face

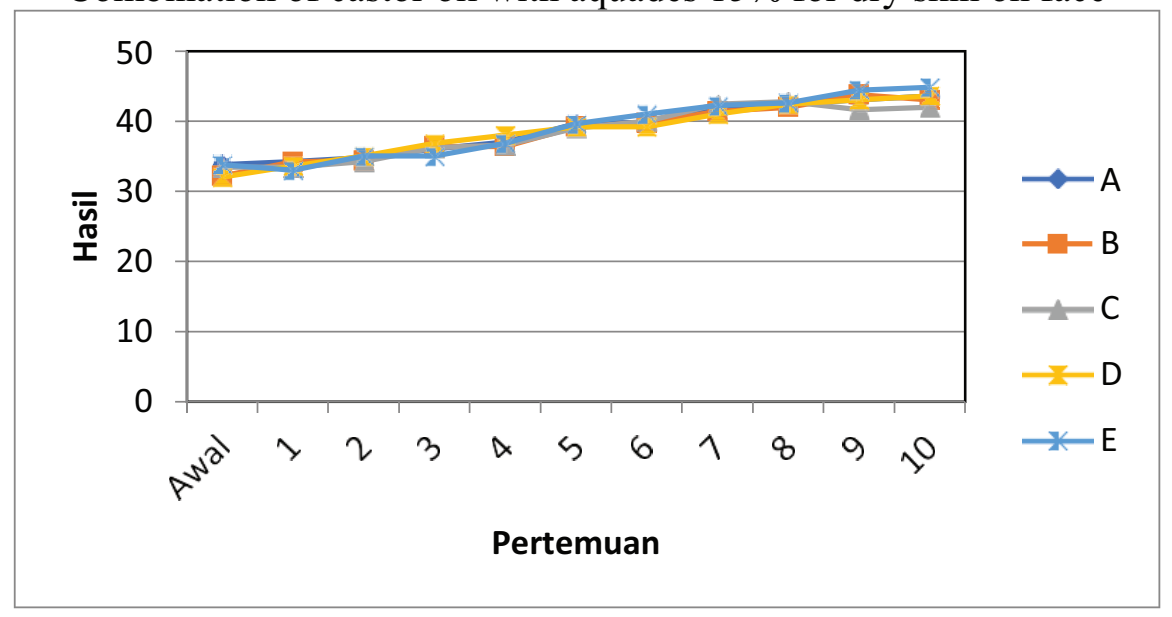

The results on graphic of increased levels of humidity dry skin on face using essential oil blend of castor oil with aquades $15 \%$ is increase moisturizing dry skin after treatment.

Combination of castor oil with aquades $10 \%$ for dry skin on elbow

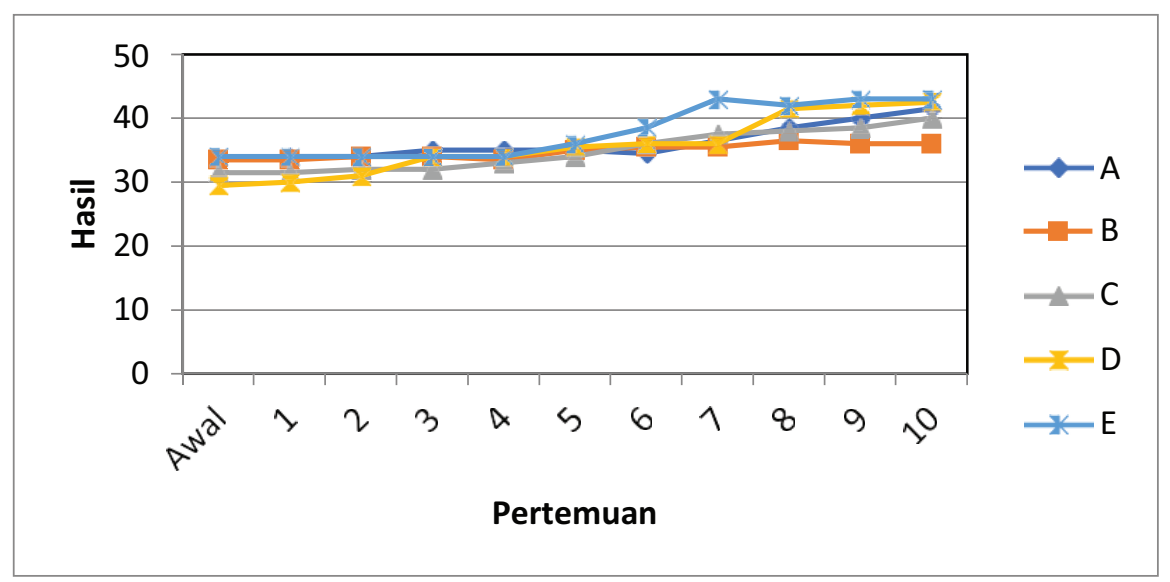

The results of the research data shows the score increased levels of moisture to dry skin at the elbow after treatment that use a mixture of essential castor oil with aquades $10 \%$. 
Combination of castor oil with aquades $5 \%$ for dry skin on heel

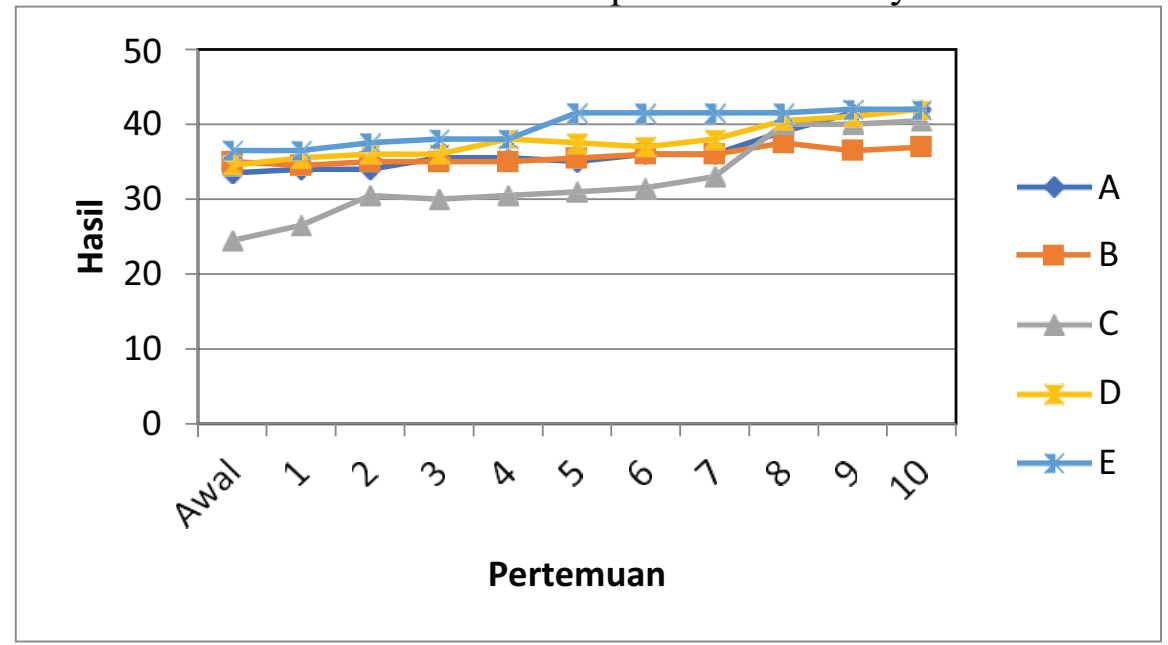

The results showed score increased levels of moisture dry skin foot heel section which uses blend of castor oil with aquades $5 \%$. So from the graphic above it can be seen that the mixture of castor oil with aquades has an increase dry skin.

\section{Discussion}

Research on the influence blend of castor bean with aquades has been done to the 15 samples, which are divided into 3 groups: Group A sample of dry facial skin is as much as 5 people, Group B is a sample dried elbow skin as many as 5 people and Group $C$ skin dry feet heels sample as many as 5 people. Data research results on dry skin moisture for the third group of each group with use castor oil with aquades 15\%, Group B use essential oil castor with aquades $10 \%$ and C essential uses Castor oil 5\%. The results of increased levels of humidity dry facial skin using of castor oil with aquades $15 \%$ on a number of 5 samples have a range between 1.71 to 1.86 with total value amounted to 8.86 and scores an average of 1.77 so It is said that data increase and data shows the score increased levels of moisture to dry skin a number of 5 samples at the elbow that use a mixture of castor oil with aquades $10 \%$. The increase in the numbers of this moisture is visible from a range of numbers between 1.05 to 1.40 with a total value of 6.20 and value an average of 1.24. The test can be seen on its homogeneity test of Homogeneity of Variances is visible the value of Level of 1.360 results obtained Statistics and probability values of 0.230 which is above the standard of 0.05 , which means error variance data from initial meeting to the meeting to 10 is homogeneous or have the same variance. Improvement of Essential Oil Treatment Outcome Data castor bean With Aquades 10\%. In the table of mean values obtained from the descriptive initial meeting to meeting 10 . Seen from the results at each of the meetings has increased. 
The test can be seen on its homogeneity test of Homogeneity of Variances is visible the value of Level of 1.796 results obtained Statistics and probability values of 0.090 which is above the standard of 0.05 , which means error variance data from initial meeting to the meeting to 10 is homogeneous or have the same variance. The test can be seen on its homogeneity test of Homogeneity of Variances is visible the value of Level of 0.480 results obtained Statistics and probability values of 0.894 which is above the standard of 0.05 , which means error variance data from initial meeting to the meeting to 10 is homogeneous or have the same variance. The results showed score increased levels of moisture dry skin foot heel section which uses essential oil blend of castor bean with aquades $5 \%$ on 5 samples have a range between 2.15 to 2.57 with total value amounting to 11.61, value an average of 2.32. On the test of the hypothesis of $F$ calculating 0.641 value obtained, while the value of the probability of 0.544 which is above the level of error that is 0.05 , means there is no significant difference between essential oil blend of castor bean with aquades 15\%, 10\%, and 5\%. From these results it can be concluded that the three experimental results with aquades $15 \%, 10 \%$, and $5 \%$ have the same quality. Data from the research results on a dry facial skin using blend of castor bean with aquades $15 \%$, there was a rise in the value of the Aquades data means $0.24615 \%$ on facial skin. So it can be said that there is a significant increase in dry facial skin. From the results of research on dry elbow skin using essential oil blend of castor bean with aquades $10 \%$, there was a rise in the value of the mean of the data Aquades $0.27910 \%$ on Elbow. So it can be said that there is a significant increase in dry elbow. From the results of research on the heels of the feet dry skin using blend of castor bean with aquades $5 \%$, there was a rise in the value of 0.254 . So it can be said that there are increased levels of moisture to dry skin on the feet. Descriptive obtained value table on mean test results blend of castor bean with aquades 15\%,10\%, and 5\% difference is not seen. On the test of the hypothesis of $F$ calculating 0.641 value obtained, while the value of the probability of 0.544 which is above the level of error that is 0.05 , means there is no significant difference between Aquades 15\%, 10\% and 5\%. From these results it can be concluded that the results of the experiment that is third (aquades 15\%, 10\% and 5\%) have the same quality. So the results of the study known alternative hypothesis stating there the influence of the use of castor bean with aquades against moisture results in dry skin, thus $\mathrm{HO}$ is rejected and accepted, meaning there are $\mathrm{H} 1$ the influence of use of castor oil with aquades against moisture results in dry skin. 


\section{Conclusion}

Castor oil is very good in helping moisturize the dry skin, especially for heel dry skin care. Using a mixture of castor oil and aquades can both increase the moisture content of the skin. Based on the results of research on a number of 15 samples selected according to criteria, obtained calculations that show the average value of the increase in skin moisture. This is due to castor oil seed containing very high coarse fat, castor seed oil contains ricin, dehydrosistrearat, palmitic acid, stearate acid, oleic acid, linoleic acid, linoleic acid, emollient / dioxytyl azelate linoleic acid which can give effect to increase moisture in dry skin while distilled water is neutral but useful to help infiltration of castor oil on the skin of dry feet. Therefore, the less mixture of aquades as a mixture of castor oil, the more it will impact to moisturize dry skin. Research that has been carried out on a dry facial skin using blend of castor oil with aquades $15 \%$, there was a rise in the value of 0.246 research have been conducted on dry elbow skin using mix castor oil with aquades $10 \%$, there was a rise in the value of 0.279 research have been conducted on the heels of the feet dry skin using blend of castor oil with aquades $5 \%$ increase of 0.254 , occurred while the value of the probability of 0.544 which is above the level of error that is 0.05 , means there is no significant difference between Aquades $15 \%, 10 \%$ and $5 \%$.

\section{References}

[1] Tranggono dan Latifah (2007) Buku Pegangan Ilmu Pengetahuan Kosmetik. Jakarta: Gramedia Pustaka Utama.

[2] Kustanti, Herni. (2008: 71) et al. 2008. Tata Kecantikan Kulit. Jakarta: Direktorat Pembinaan Sekolah Menengah Kejuruan

[3] Novel, S. (2014:5). Rahasia cantik Alami Bebas Jerawat. Jakarta: Gramedia.

[4] Astuti, K. Widnyani, et al. Uji Pendahuluan Nilai Kelembaban Kulit Manusia Pada Pemakaian Sediaan Masker Gel Peel Off Kulit Buah Manggis. Jurnal Kimia, [S.I.], p.50-53, jan 2018. ISSN 2599-2740. Available at: $<$ https://ojs.unud.ac.id/index.php/jchem/article/view/37333>.

[5] Tranggono, R \& Latifah, F. (2007: 78). Buku Pegangan IImu Pengetahuan Kosmetik. Jakarta: Gramedia Pustaka Utama.

[6] Kapoor Shweta, Saraf Swarnlata. Formulation and Evaluation of Moisturizer Containing Herbal Extracts for the Management of Dry Skin. Pharmacognosy Journal. 2010. Vol 2, Issue 11. 409- 417 
[7] Sujatmaka, 1992: h. 21 Prospek Pasar dan Budidaya Jarak. Jakarta: Penebar Swadaya

[8] Atul N Chandu et al., A rievew: Herbs Used As Moisturizing Cream For Skin Treatment. Indo American Journal of Pharm Research. 2011:1(1);8-17

[9] Sujatmaka (1992:19-21). Prospek Pasar dan Budidaya Jarak. Jakarta: Penebar Swadaya

[10] Soenardi, et al. (2004) Prosiding Lokakarya Pengembangan Jarak dan Wijen Dalam Rangka OTODA.

[11] Mulatama Laboratorium. Jasa Laboratorium Industri dan Makanan. (2018) Jakarta.

[12] Fransisca Bayu Hantari. Pengaruh Penggunaan Almond (Prunus Dulcis) Sebagai Masker Wajah Terhadap Kelembaban Kulit Pada Wajah Kering. Jurnal Tata Rias. Vol 6 No 62014

[13] Renuve Speeed+Depth. Guide Book Skin Analyzer Test. 2018 